Article

\title{
The Roles of Perceived Innovativeness in Creating Visitors' Citizenship Behaviors at an International Game Exhibition
}

\author{
Sooyoung Choi ${ }^{1}$, Young-joo Ahn ${ }^{2}$ and Insin Kim ${ }^{1, * \mathbb{D}}$ \\ 1 Department of Tourism and Convention, Pusan National University, Pusan 46241, Korea; sychoi@pusan.ac.kr \\ 2 College of Hospitality and Tourism Management, Sejong University, Seoul 143747, Korea; \\ yj.joanna.ahn@gmail.com \\ * Correspondence: insinkim@pusan.ac.kr; Tel.: +82-51-510-3005
}

Received: 1 May 2020; Accepted: 16 June 2020; Published: 17 June 2020

check for updates

\begin{abstract}
This study examines the extent of game exhibition visitors' perceptions of innovativeness through service quality and investigates the relationships between innovativeness and visitors' citizenship behavior, which are the more active behaviors compared with loyalty in game exhibitions. Data were collected from game exhibition visitors participating in Game Show \& Trading, All-Round (G-STAR), one of the largest international exhibitions supporting the game industry in South Korea. The results reveal that all three service quality dimensions were important antecedents of innovativeness. The results also verify that innovativeness has positive effects on citizenship behavior toward other visitors and G-STAR, and membership positively moderates the relationship between innovativeness and citizenship behavior toward other visitors. These results suggest that a conceptual model for understanding the dynamic effects of the relationships between service quality, innovativeness, and visitors' citizenship behavior can be constructed and can contribute to managing sustainable exhibitions in the game industry.
\end{abstract}

Keywords: innovativeness; service quality; servicescape; booth staff service; core service; visitor citizenship behavior; international game exhibitions

\section{Introduction}

The global game market saw more than 2.5 billion gamers across the world in 2019 [1]. The market generated a total of $\$ 152.1$ billion in 2019 , a $9.6 \%$ increase from the previous year, and is expected to grow to $\$ 196$ billion by 2022 [1]. The South Korean game industry, the fourth largest in the world, accounts for $6.3 \%$ of the global games market and made $\$ 5.6$ billion in revenue in 2018 [2,3]. Consumer-led gaming trends have been relentlessly changing, making a dramatic shift from video games to console, mobile, virtual reality, augmented reality, etc. [4]. As the industry draws in more game consumers, companies in the global game industry face an increasing pressure to differentiate themselves in the marketplace because they compete in one of the most rapidly growing and competitive markets [5]. The volatile habits of game consumers and the rapidly developing technology generate game consumers' high expectations and result in demands for new, creative, and innovative ways for them to engage with and through games [6]. From this perspective, international game exhibitions can be an effective way to increase sales opportunities, introduce new products and technologies, and provide opportunities for interactions between exhibitors and visitors $[7,8]$. The primary objectives of exhibitions are to sell and advertise new products and services, facilitate brand communication between exhibitors (i.e., game companies) and visitors, and expand interactive business networks [9]. In addition, exhibitions foster economic development and bring about new cultures in the host destinations [10]. Therefore, 
international game exhibitions must facilitate innovativeness by providing new experiences and increasing knowledge of innovative products and services in the exhibition venue [11]. Visitors' perceptions of innovativeness may play an important role in better understanding the adoption of new products, consumption patterns, and positive behavioral intentions [12-14]. While some have examined innovativeness in hospitality and tourism contexts such as restaurants [15], museums [16], tourism websites [17], and sports events [18], only a few studies have focused on international game exhibitions as globally popular and effective marketing events (e.g., [19]).

This study assumed that visitors' perceptions of innovativeness are formed through their individual experiences and awareness of the introduced products, services, and technologies during a game exhibition, and that it influences their supportive behavior toward the venue. Many studies have called for a better understanding of the reciprocal and beneficial relationships facilitated through co-creation in hospitality and tourism management [20-22]. However, few have focused on the role of visitors as co-creators and co-producers, who can enhance other visitors' event experiences and create an informative atmosphere within the venue. Visitors' supportive and helping behaviors (citizenship principles) toward other visitors and an exhibition may be key factors influencing the successfulness and competitiveness of international game exhibitions [23]. In addition, such behaviors can help international game exhibitions achieve their goals of increasing awareness of the new products and features of exhibitors and facilitating the collection of valuable information on market responses.

This study adopted the service-dominant logic framework to explore this co-creation process [24,25]. The proposed model suggests that various dimensions of service quality can influence game exhibition visitors' behavioral intentions because they perceive such value-added components as innovativeness. This study empirically tested whether service quality influences innovativeness and whether innovativeness affects visitors' citizenship-style behavior toward other visitors and the game exhibition [26]. Furthermore, this study investigated the moderating role of the membership level as perceived by a visitor of a game exhibition in the relationships between innovativeness and the visitors' citizenship behavior. The results of this study contribute to the literature by providing a better understanding of the process through which visitors engage with an exhibition venue. In addition, this study contributes to the literature on co-creation experiences by providing empirical evidence of relationships among service quality, innovativeness, and visitor behavior based on citizenship.

\section{Theoretical Background}

\subsection{Innovativeness}

Perceived innovativeness refers to "the consumer's perception of an enduring firm capability that results in novel, creative, and impactful ideas and solutions" [14] (p. 817), while innovativeness represents the capability of a firm to introduce innovative products and provide new ideas and solutions [15,27]. Hurley and Hult [28] viewed innovativeness as the willingness of a firm to adopt new technologies and ideas in order to provide innovative products to consumers faster than its competitors. The level of innovativeness is subjective because it depends on consumer perceptions based on their information, knowledge, and experience with respect to the firm [14,29]. Major characteristics of innovativeness include novelty, newness, uniqueness, and differentiation in the minds of consumers [27]. Therefore, consumers are more likely to perceive a firm as innovative when it stimulates and excites them, provides new experiences, and influences their consumption patterns $[12,13,30]$. In addition, consumers who tend to respond to innovative products and services are more likely to adopt new products earlier than others and interpret stimuli into meaningful experiences and knowledge [26].

Previous hospitality and tourism studies have employed innovativeness to understand the inherent personality characteristics of patrons who prefer to try new offerings at restaurants [15] and museum visitors that adopt new podcasting technologies [16,31,32]. Such studies have employed the concept of innovativeness as reflecting the tendency to adopt innovations [33]. For example, 
the researchers examined consumers' innovativeness in terms of information searches, purchases, and communication behaviors on tourism websites [17] and the effect of consumers' innovativeness regarding destination on parasocial interaction when using tourism websites [34]. However, the present study views innovativeness as the important perceived value of an event experience that can lead to a positive behavioral change. In the same vein, Yoshida and colleagues [18] referred to innovativeness in sports events primarily as spectators' perceptions of an event's newness and uniqueness. This enabled them to propose various dimensions of innovativeness in the context of sports events (including event innovativeness, satisfaction, and behavioral intentions) and to examine their relationships using data collected from 335 spectators of a college football game. Their study demonstrated the positive effects of these dimensions on attitudinal and behavioral outcomes (e.g., loyalty) mediated by event innovativeness.

In this regard, our understanding of which dimensions of exhibition service quality foster visitors' perceptions of innovativeness is central to developing successful marketing strategies [17]. In terms of game industry exhibitions, innovativeness plays a key role in their success because the primary goal of any such exhibition is to introduce new and innovative game products and technologies to potential markets [30]. This study is more comprehensive in that it focuses on visitor perceptions of the innovativeness of the entire exhibition.

\subsection{Service Quality}

Service quality can be defined as "the consumer's judgment about the overall excellence or superiority of service" [35] (p. 3). A number of service quality measures have been suggested. However, there is no general consensus on how service quality should be conceptualized and operationalized [36-38]. Cronin and Taylor [36] indicated that many studies have adopted Parasuraman and colleagues' [39] Service Quality (SERVQUAL) scale, which can be viewed as the difference between performance expectations and perceptions based on five dimensions: tangibility, reliability, responsiveness, assurance, and empathy. Nevertheless, the SERVQUAL scale has been criticized because of its lack of information on service outcomes and service delivery processes $[19,24,37,40]$. In this regard, Brady and Cronin [40] extended Rust and Oliver's [38] model and proposed three dimensions of service quality-the quality of personal interactions, the quality of the physical environment, and outcome quality - to categorize each independent service outcome in the service delivery process $[37,40]$. High service quality motivates consumers to visit a particular venue, to have certain values, or to purchase products and services, and is closely related to customer satisfaction, repurchase intentions, and overall profitability [7,41-46].

Many studies have provided evidence supporting the relationship between overall service quality and the value added in a hospitality and tourism setting (e.g., [18,47]). For example, Jin and colleagues [9] examined the relationships between service quality, perceived value, destination image, and behavioral intentions in the context of a mega-sports event by using data collected from international tourists who attended the International Association of Athletics Federations World Championship in Daegu, South Korea. Their findings demonstrated the positive impact of event quality on its perceived value. Kyle, Theodorakis, Karageorgiou, and Lafazani [41] evaluated ski resort services, based on a combination of elements related to interaction quality (staff services), facility quality, and outcome quality, and found positive effects of service quality on skiers' satisfaction and loyalty. Gottlieb and colleagues [19] examined the relationships between service quality, service outcomes, and visitors' perceptions of events' effectiveness in the context of trade shows. They included trade show interaction quality (i.e., attitudes, behavior, and expertise of service personnel), trade show environmental quality (i.e., ambient conditions, design elements, and social factors), and trade show outcome quality (i.e., favorable perceptions of waiting time, tangibles, and valence-whether the outcome is good or bad). They revealed that such trade show service quality was positively related to the trade show's perceived effectiveness and the overall attitude toward the trade show experience. Therefore, three-dimensional services can provide important implications for how added value can be created through international 
exhibitions. In particular, innovativeness in the game industry is an important driver of positive outcomes. This study identifies the most important dimensions of service quality in the formation of innovativeness in the context of an intensive experiential exhibition, such as a game exhibition.

\subsubsection{The Servicescape}

The servicescape refers to physical attributes such as ambient conditions, designs, and facilities $[40,48]$. Since services are intangible, the surrounding physical environment can influence service perceptions [40]. The servicescape includes any tangible aspects of service sites, facilities, and equipment, and these physical properties of the servicescape can provide important tangible cues for behavior $[48,49]$. Prior studies have demonstrated that physical facilities play a fundamental role in evaluating service quality in festival and event contexts [7,50-52].

Tangible service quality and physical environment cues can foster event innovativeness [18,53]. More specifically, Kyrgidou and Spyropoulou [53] examined the relationships between various drivers (e.g., managerial, entrepreneurial, and technical capabilities), innovativeness, and performance by using data from 218 Greek manufacturers, and they revealed that manufacturers are more likely to perceive a firm as being innovative if it has sufficient technological knowledge, applies recent technological developments, and produces novel products and technological equipment in a timely manner. Yoshida and colleagues [18] suggested some important factors facilitating the overall innovativeness of sports events and found that new and unique technological products (e.g., wide-screen TV sets) in the sports stadium can facilitate spectators' perceived innovativeness. In the present study, the servicescape includes tangible components of international exhibitions that are associated with any physical service's attributes which are evaluated by exhibition visitors, such as convention centers, equipment for playing trial games, facilities, restaurants, and the physical appearance of service providers. In this regard, the following hypothesis is proposed:

Hypothesis 1 (H1). The servicescape has a positive effect on innovativeness.

\subsubsection{Booth Staff Service}

Employee service refers to customers' evaluation of service providers' service performance and attitudes. Employees' service performance in labor-intensive service businesses can have a considerable influence on customers' perceptions of service quality because of the intangibility and inseparability of services [54,55]. Employee service can be assessed by how well service providers treat customers who perceive intangible services in the service delivery process and indicates the extent to which service providers and customers interact with each other [56]. These interactions with service providers delivering promises of intangible services can influence customers' experiences [40]. Berry [54] pointed out that service providers play an essential role in the labor-intensive service sector. Employee service increases the level of recognition for the firm's brand, facilitates the formation of a brand's meaning, and influences brand loyalty. In terms of firms offering new technologies, service providers can reduce consumers' perceived risk and promote trust [57].

Previous tourism and hospitality studies have provided ample evidence that employee service fosters added value (e.g., [49,58]). For example, Alexandris et al. [59] demonstrated that employee service plays an important role in increasing customer satisfaction and the value of place attachment. Jin, Lee, and Lee [9] found that well-educated employees' service facilitates a positive image of the host destination among visitors. Gottlieb, Brown, and Drennan [19] indicated that booth employees at trade shows provide educational information to visitors through various activities such as hands-on demonstrations and presentations. The present study views booth staff's service as an essential factor in fostering event innovativeness. For example, booth staff members can serve as facilitators delivering new information on products and equipment, provide detailed instructions to new game players, answer specific questions, and help visitors solve technical problems at the venue. Booth staff members 
who are trained before the exhibition are knowledgeable experts about firms' new product features and benefits and can strengthen visitors' perceptions of innovativeness by explaining how new products are developed. As a result, visitors are likely to perceive booth staff as having novel, creative, and impactful ideas and thus perceive them as innovative [14]. In this regard, the following hypothesis is proposed:

Hypothesis 2 (H2). The booth staff's service has a positive effect on innovativeness.

\subsubsection{Core Service}

The service evaluation continues while consumers experience the service provided [60,61]. During service delivery, the service provided (i.e., core service) and the way the service is delivered (by a person) (i.e., the employee service) are the basic evaluation criteria of the service $[60,62]$. Indeed, the core service refers to "the processes by which the service is delivered" [60] (p. 128) and consumers' evaluation of actual service outcomes (e.g., the waiting time and the punctuality of service providers) affecting the consumers' purchase decision to select services $[38,40,63]$. Therefore, unlike the servicescape, the core service as well as the behaviors of service employees are the intangible elements of service that are not easily seen or known in the pre-consumption stage. Accordingly, previous research has demonstrated that the core service can be assessed based on the various experiential components of individuals and can vary between different contexts. For example, Grace and O'Cass [60] defined the core service of a retail store as "providing shoppers with access to merchandise," "displaying merchandise," "giving advice to shoppers regarding merchandise," "appropriately packing merchandise for shoppers to take away," "providing delivery options for shoppers," and "providing payment options for shoppers" (p. 136). In Gottlieb, Brown, and Drennan's [19] study, the outcome quality of trade shows was measured with components such as "waiting time for service at booths or for entry to the show, the suitability of the exhibitor mix, and overall attitudinal disposition toward the service experience" (p. 1646) and found a positive relationship between outcome quality and trade show service quality. Kyle, Theodorakis, Karageorgiou, and Lafazani [41] tested the three-dimensionality of service quality in a ski resort setting in a first-order model and found a direct relationship between outcome quality (i.e., the core service) and satisfaction.

In this study, the core service that game exhibitions provide can include services such as showcasing and selling newly-released or soon-to-be released games, providing information on games that are in development, selling game merchandise, holding e-sports matches, and holding seminars or press conferences on the game industry. Since game exhibitions are characterized as facets of new technologies, high-tech game environments, and exciting e-sports matches, the positive evaluation of the core service may increase the level of innovativeness as perceived by visitors (i.e., perception of the novelty, newness, uniqueness, and differentiation of a game exhibition). Therefore, this study posits that the core service as assessed by visitors' interpretations can be hypothesized to form the perceived innovativeness of a game exhibition, as follows:

Hypothesis 3 (H3). The core service has a positive effect on innovativeness.

\subsection{Innovativeness and Customer Citizenship Behavior toward other Visitors and toward the Game Exhibition}

Customer citizenship behaviors are defined as "voluntary and discretionary behaviors that are not required for the successful production and/or delivery of the service but that, in the aggregate, help the service organization overall" [64] (p. 11). This behavior represents helpful, voluntary, and favorable principles of behavior toward other customers and a service provider [23,64-66]. Customer citizenship behavior is beneficial to both other customers and an organization. In fact, Yi and colleagues [23] insisted that an analysis of customer citizenship behavior should be conducted separately based on its beneficiaries: customer citizenship behavior toward customers (e.g., giving helpful information to new customers and sharing extra vouchers or discount coupons with other customers) and toward the 
firm (e.g., recommending the firm to others and suggesting ideas for improving services). Customers who show a high level of customer citizenship behavior are more likely to share favorable service experiences, have referral intentions, and help other customers who lack knowledge on how to use products and services appropriately during service encounters [65]. In addition, customers who are active in the service delivery process and tend to show extra-role behaviors are more likely to report problematic issues in service delivery to service providers and suggest solutions to service failures in proactive ways [67]. Therefore, customer citizenship behavior strengthens customers' long-term preferences for a service provider and facilitates the service provider's performance and long-term success by enhancing service input and providing a service provider with the required resources $[23,64]$.

Only a few studies have empirically examined the effects of perceived innovativeness on visitors' citizenship behavior toward other visitors and the event in an exhibition setting. In this regard, this study examines visitors' citizenship behavior to better understand it in the context of game exhibitions. As mentioned earlier, the service quality stimuli, such as service environments, staff service, and the service provided, can enhance visitors' overall evaluations of exhibition services [12,13]. Visitors who perceive the high innovativeness of a game exhibition are likely to evaluate such service stimuli as meaningful experiences and hold a positive attitude toward the game exhibition and its services, which eventually affects the visitors' behavior [26]. Moreover, innovativeness as the added value of the game exhibition experience may lead to more favorable attitudes and behaviors, so that the visitors act in ways that are more beneficial to the exhibition and other visitors. That is, when visitors perceive some desired value, such as innovativeness, they may purchase products and services or show supportive behaviors within the exhibition [21,23,35]. In this regard, the following hypotheses are proposed:

Hypothesis 4 (H4). Innovativeness has a positive effect on visitors' citizenship behavior toward other visitors in the exhibition venue.

Hypothesis 5 (H5). Innovativeness has a positive effect on visitors' citizenship behavior toward the exhibition.

\subsection{The Moderating Role of Membership}

The social identity theory developed by Tajfel and Turner [68] posits that individuals tend to classify themselves into different social groups based on their affiliations, membership, and age. In this study, membership is defined as the perception and awareness of one's membership in an exhibition. Membership is considered as an important predictor of exhibition visitors' willingness to engage in extra-role behaviors in the exhibition venue. Previous studies have shown that a sense of belonging facilitates active participation in knowledge sharing [69-71]. For example, Chai and Kim [70] explored how social factors influence users' knowledge sharing through social networking sites by considering 211 users of these sites. Their findings revealed that those users with a strong sense of belonging to social networking sites were more likely to actively contribute to knowledge sharing.

However, previous festival and event studies have paid little attention to the moderating roles of membership and visitors' citizenship behavior in facilitating exhibition visitors' extra-role behaviors at the exhibition venue. Yi and colleagues [23] insisted that membership is an important moderator and investigated the role of a customer's social identity as a moderator of the relationship between other customers' citizenship behaviors and the subject customer's citizenship behavior toward other customers and the firm. They demonstrated that social identity positively moderates the relationship between other citizenship behaviors and customer citizenship behavior toward others and the firm. This suggests that visitors who perceive themselves as members of a special event are likely to actively engage in extra-role behaviors toward others and the event. In this regard, the following hypotheses are proposed: 
Hypothesis 6a (H6a). Membership positively moderates the relationship between innovativeness and visitors' citizenship behaviors toward other visitors.

Hypothesis $\mathbf{6 b}$ (H6b). Membership positively moderates the relationship between innovativeness and visitors' citizenship behaviors toward the exhibition.

Figure 1 illustrates the research framework for this study.

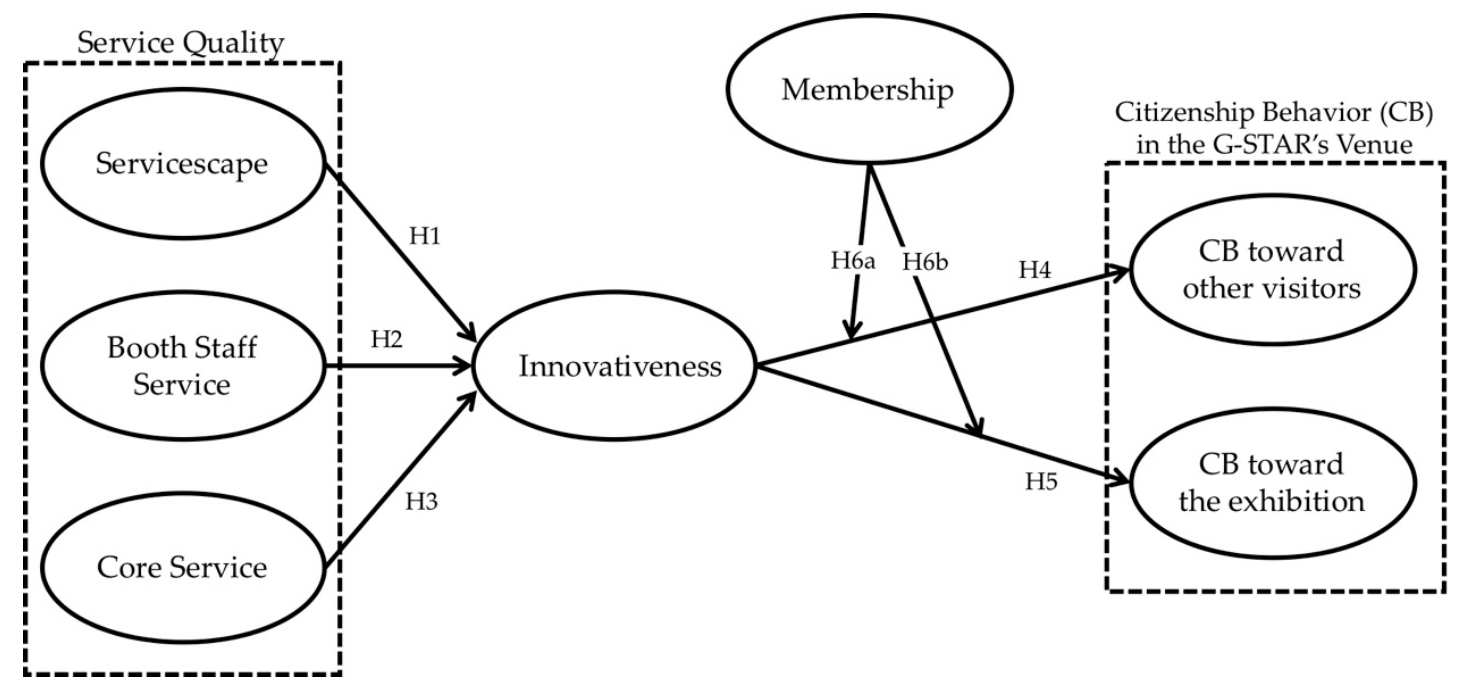

Figure 1. Research framework for this study.

\section{Materials and Methods}

\subsection{The Research Setting}

Game Show \& Trading, All-Round (G-STAR), the fourth-largest game exhibition in the world and the largest South Korean game exhibition, was selected to test the proposed model. G-STAR 2014 took place from November 20-23, 2014 at the Busan Exhibition and Convention Center (BEXCO) in Busan, the second-largest city in South Korea, with 3.7 million residents [10]. The slogan of G-STAR 2014 was "Game Is Not Over," reflecting the game industry's determination to overcome a market crisis caused by strict government regulations, competitiveness, and diverse game users' high expectations in terms of graphics, game genres, and game hardware [72]. A total of 617 game firms from 35 countries participated in G-STAR 2014, and about 200,000 people visited G-STAR 2014 [73].

G-STAR provides opportunities for showcasing new games developed by leading global game publishers, facilitating the export of new games, and investing in new games and technologies. In addition, G-STAR is designed to help promote start-up and small game firms and provide on-site recruitment opportunities for job seekers [72]. The global game exhibition has considerable influence on potential markets and provides important insights for positioning new products and technologies. In this regard, by considering the case of G-STAR, this study examines the processes through which innovativeness is created through service quality and the supportive behaviors of visitors are fostered.

\subsection{Measures}

Three main constructs were measured, using items from previous research, to empirically test the proposed model: service quality, innovativeness, and visitors' citizenship behaviors within the exhibition venue. Based on previous research [60], the measures of service quality were derived. For the initial questionnaire, items fitted for game exhibitions were selected based on interviews and discussions by three expert groups in the meeting, incentive travel, convention, and exhibition (MICE) industry: (1) professors whose research fields included the MICE industry, (2) graduate students 
majoring in hospitality and tourism management, and (3) managers and executives working for convention centers. In this process, inappropriate measurement items in the convention and exhibition context among items used in previous studies were removed, and the wording of the questions was revised.

The developed instrument was pretested through 37 graduate students majoring in hospitality and tourism management. Through exploratory factor analysis (EFA), the measurement scale of service quality in the game exhibition context was purified by using component analysis and the varimax orthogonal rotation method. The Kaiser-Mayer-Olkin (KMO) value was 0.877, and the Bartlett's sphericity test results indicated the appropriate data for factor analysis $\left(\chi^{2}=1183.378, d f=55, p<0.001\right)$. The rotated factor loadings were considered significant when indicating 0.40 and higher [74]. Of ten items, one with a cross-loading on both core service and the servicescape factors should have be deleted, but we determined to load the item, "The core service of G-STAR is of high quality", on the factor with a higher loading (core service: 0.686 vs. The servicescape: 0.401 ), because only two indicators remained on the core service factor. Accordingly, three dimensions of service quality were extracted: (1) the servicescape (three items: "attractive", loading=0.734; "neat and well-dressed appearance", loading $=0.718$; "in accordance with the type of service", loading $=0.805$ ) indicating an eigenvalue of 2.600 , variance explained $26.0 \%$; (2) booth staff service (four items: "prompt attention", loading=0.703; "willing to help me", loading=0.758; "never too busy to respond to my requests", loading=0.824; "polite", loading $=0.725$ ) indicating an eigenvalue of 2.096, variance explained 20.9\%; and (3) core service (three items: "suits my needs", loading $=0.744$; "reliable", loading $=0.849$; "high quality", loading $=0.686$ ) indicating an eigenvalue of 2.102 , variance explained $21.0 \%$.Innovativeness included five items [14]. Visitors' citizenship behaviors in the exhibition venue included two subscales [23]: (1) visitors' citizenship behaviors toward other visitors, with three measurement items and (2) visitors' citizenship behaviors toward the exhibition, with three measurement items. Membership was measured using five items derived from Koh and Kim [75] and Lin [76]. For each item, respondents were asked to give a score based on a 5-point Likert scale, from 1 (strongly disagree) to 5 (strongly agree).

\subsection{Data Collection and Analysis}

An on-site survey was administered only to domestic visitors located at the exits of BEXCO during G-STAR 2014, held in Busan, South Korea, from November 20-23, 2014. A trained research team conducted the survey at BEXCO and the convenient sampling method was employed for the on-site field situation. The field research team asked whether respondents had experienced G-STAR held at BEXCO and if they were willing to participate in the survey. Willing respondents were provided with a brief explanation of the purpose of the study and given the questionnaire. All respondents completed the questionnaire voluntarily, and 282 responses were collected. After excluding responses with missing information, a total of 255 individuals were used for further data analysis.

The hypotheses for the proposed model were tested using structural equation modeling (SEM), based on SPSS 19.0 and AMOS 18. SEM is a useful tool for evaluating the succession of dependent relationships and verifying cause-and-effect relationships between multiple independent and dependent constructs [74]. Based on Anderson and Gerbing [77], a two-stage testing procedure was used. In the first stage, a confirmatory factor analysis (CFA) was conducted to assess the uni-dimensionality of the scales for each construct. In the second stage, the relationships in the structural equation model were tested.

\section{Results}

\subsection{Demographic Profiles}

Table 1 describes the survey respondents' demographic profiles. The sample $(N=255)$ included more males $(70.1 \%)$ than females. In terms of occupation, $60.8 \%$ were students, $11.4 \%$ were employees, and $7.1 \%$ were professionals. In terms of age, $84.7 \%$ of the respondents belonged to the $20-24$ and 
$25-29$ age groups, and the mean age was approximately 25 years. In terms of education, $41.6 \%$ had a high school diploma and $40.0 \%$ had a bachelor's degree. In summary, the respondents were generally young male adults, and the randomly selected subjects were therefore well representative of the visitors of G-STAR as well as the global games market $[78,79]$.

Table 1. Profiles of respondents $(N=255)$.

\begin{tabular}{cccc}
\hline Characteristics & Categories & $\boldsymbol{n}$ & $\boldsymbol{\%}$ \\
\hline \multirow{2}{*}{ Gender } & Male & 181 & 71.0 \\
& Female & 74 & 29.0 \\
\hline \multirow{2}{*}{ Education level } & High school diploma & 106 & 41.6 \\
& Some college & 37 & 14.5 \\
& Bachelor's degree & 102 & 40.0 \\
& Graduate degree & 10 & 3.9 \\
\hline & Company employee & 29 & 11.4 \\
Occupation & Professional & 18 & 7.1 \\
& Student & 155 & 60.8 \\
& Government employee & 7 & 2.7 \\
& Other & 46 & 18.1 \\
\hline \multirow{2}{*}{ Age } & 20-24 & 153 & 60.0 \\
(Mean age: & 25-29 & 63 & 24.7 \\
25 years old) & 30-34 & 25 & 9.8 \\
& 35 and above & 14 & 5.5 \\
\hline
\end{tabular}

\subsection{The Measurement Model}

Table 2 shows the results of CFA with the measurement items and their standardized factor loadings. Factor loadings ranged from 0.605 to 0.852 and were significant at $p<0.001$, indicating sufficient convergent validity [74]. The CFA results showed that the overall fit of the measurement model was statistically acceptable: $\chi^{2}=285.697 ; \chi^{2} / d f=1.642 ; d f=174$; comparative fit index (CFI) $=0.959$, incremental fit index (IFI) $=0.959$; Tucker-Lewis index $(\mathrm{TLI})=0.950$; root mean square error of approximation (RMSEA) $=0.050$ (see Table 3 ). The model thus showed satisfactory fit indices [80] The average variance extracted (AVE) exceeded 0.50 for all the proposed constructs [81], indicating sufficient convergent validity with satisfactory factor loadings on the constructs in the measurement model and acceptable AVE values for each construct in the measurement model [82]. Discriminant validity was assessed through CFA by comparing the squared correlation between constructs and the AVE value. As shown in Table 3, all squared correlation $\left(R^{2}\right)$ values for the pairs of constructs were lower than the AVE value of each construct, except for a pair of citizenship behaviors toward other visitors-citizenship behavior toward the exhibition. To establish their discriminant validity, a combined model was obtained by merging both constructs (i.e., citizenship behavior toward other visitors and citizenship behavior toward the exhibition) into one single construct, and its $\chi^{2}$ value was compared with that of the uncombined model [81]. The results of the $\chi^{2}$ difference test showed that $\Delta \chi^{2}$ between the combined $\left(\chi^{2}=337.539, d f=179\right)$ and uncombined models was significant at the 0.05 level $\left(\chi^{2}=51.842>\chi^{2}{ }_{0.05}(5)=11.070\right)$, verifying the sufficient discriminant validity of both constructs. In addition, the composite reliability of all the intended constructs exceeded the recommended threshold of 0.70 [74]. These results indicate the sufficient internal consistency of the measurement items for all the constructs. 
Table 2. Cronbach's alpha reliability and factor analysis (items and loadings).

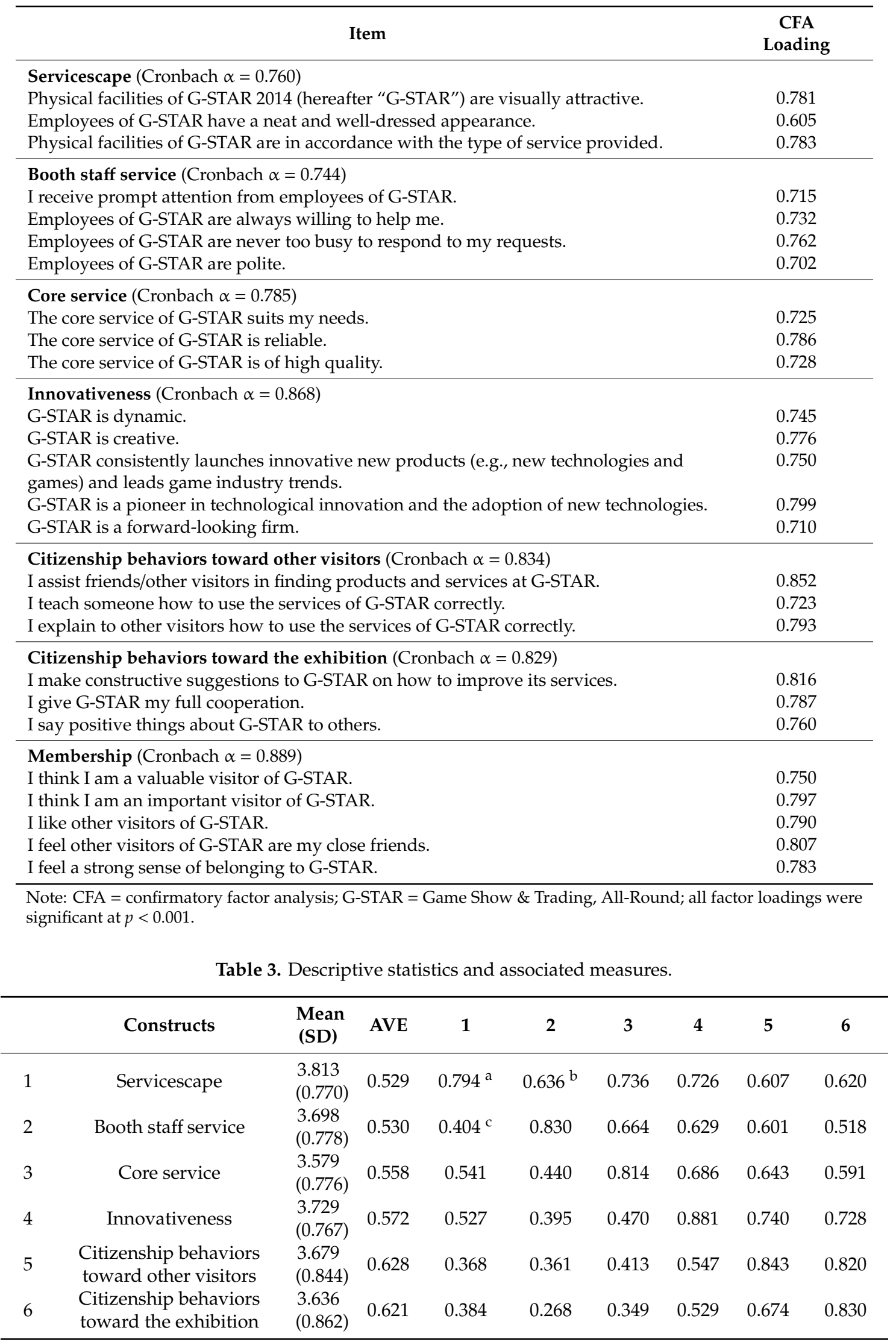

Note: $\mathrm{SD}$ = standard deviation; $\mathrm{AVE}$ = average variance extracted; ${ }^{\text {a }}$ composite reliability is indicated along the diagonal; ${ }^{\mathrm{b}}$ correlations are above the diagonal; ${ }^{\mathrm{c}}$ squared correlations are below the diagonal. 


\subsection{The Structural Model}

The structural model was analyzed to empirically test the hypotheses. Table 4 summarizes the results. Using the fit indices based on AMOS, the model provided an acceptable fit to the data $\left(\chi^{2}=334.940 ; \chi^{2} / d f=1.850 ; d f=181 ; \mathrm{CFI}=0.943, \mathrm{IFI}=0.944 ; \mathrm{TLI}=0.934 ; \mathrm{RMSEA}=0.058\right)$, and the results revealed that the overall fit of the structural model was satisfactory [80]. In terms of service quality, all dimensions of service quality, the servicescape $(\beta=0.406, p<0.05)$, booth staff service $(\beta=0.214, p<0.05)$, and core service $(\beta=0.278, p<0.05)$ had positive effects on innovativeness. These results support $\mathrm{H} 1$ to $\mathrm{H} 3$. The results indicate the positive effects of service quality on the formation of innovativeness. In addition, innovativeness $(\beta=0.806, p<0.05)$ was positively related to visitors' citizenship behaviors toward other visitors. Innovativeness $(\beta=0.792, p<0.05)$ was positively related to visitors' citizenship behaviors toward the exhibition. These results support $\mathrm{H} 4$ and $\mathrm{H} 5$, respectively, and highlight innovativeness as an important factor in facilitating visitors' citizenship behaviors toward other visitors and the exhibition.

Table 4. Standardized parameter estimates for the structural model.

\begin{tabular}{|c|c|c|c|c|c|c|}
\hline & & Path & & $\begin{array}{l}\text { Standardized } \\
\text { Estimate }\end{array}$ & $t$-Value & Result \\
\hline H1 & Servicescape & $\rightarrow$ & Innovativeness & 0.406 & 3.897 & Supported \\
\hline $\mathrm{H} 2$ & $\begin{array}{l}\text { Booth staff } \\
\text { service }\end{array}$ & $\rightarrow$ & Innovativeness & 0.214 & 2.551 & Supported \\
\hline $\mathrm{H} 3$ & Core service & $\rightarrow$ & Innovativeness & 0.278 & 2.636 & Supported \\
\hline $\mathrm{H} 4$ & Innovativeness & $\rightarrow$ & $\begin{array}{l}\text { Citizenship behavior } \\
\text { toward other visitors }\end{array}$ & 0.806 & 10.805 & Supported \\
\hline H5 & Innovativeness & $\rightarrow$ & $\begin{array}{l}\text { Citizenship behavior } \\
\text { toward the exhibition }\end{array}$ & 0.792 & 10.173 & Supported \\
\hline
\end{tabular}

Note: $\mathrm{H} 1=$ hypothesis $1 ; \mathrm{H} 2=$ hypothesis $2 ; \mathrm{H} 3=$ hypothesis $3 ; \mathrm{H} 4=$ hypothesis $4 ; \mathrm{H} 5=$ hypothesis $5 ; p<0.05$.

\subsection{The Moderating Effects of Membership}

The positive moderating effects of membership on the relationship between innovativeness and visitors' citizenship behaviors were assessed (H6a and H6b). The path coefficient between innovativeness and visitors' citizenship behaviors was compared between the high and low membership groups. The sum of the five items for membership was used as the moderator score. To assess the differential effects of membership for these two subgroups, the chi-square difference between the unconstrained and constrained models was examined for differences in the degree of freedom [77].

As presented in Table 5, regarding the path between innovativeness and citizenship behaviors toward other visitors, the chi-square difference between the unconstrained and constrained models was significant at the 0.05 level $\left(\chi^{2}=5.507>\chi^{2}{ }_{0.05}(1)=3.84, d f=1\right)$. For the high membership group, the path coefficient was $0.905(p<0.001)$, whereas for the low membership group, it was 0.569 $(p<0.01)$. This indicates a significant difference in the effect of innovativeness on visitors' citizenship behaviors toward other visitors between the membership levels and supports H6a. In summation, innovativeness was more effective in enhancing visitors' citizenship behaviors toward other visitors for the high membership group.

In addition, the moderating effect of membership on the relationship between innovativeness and visitors' citizenship behaviors toward G-STAR was also assessed (H6b). The chi-square difference between the constrained and unconstrained models was not significant at the 0.05 level $\left(\chi^{2}=3.603\right.$ $\left.<\chi^{2}{ }_{0.05}(1)=3.84, d f=1\right)$. This indicates no significant difference in the effect of innovativeness on visitors' citizenship behaviors toward G-STAR between the membership levels, thus providing no support for H6b. 
Table 5. Multi-group comparison test results.

\begin{tabular}{|c|c|c|c|c|c|c|}
\hline \multirow[t]{2}{*}{ Path } & \multicolumn{2}{|c|}{$\begin{array}{l}\text { High Membership } \\
\text { Group }(n=102)\end{array}$} & \multicolumn{2}{|c|}{$\begin{array}{l}\text { Low Membership } \\
\text { Group }(n=153)\end{array}$} & \multirow{2}{*}{$\begin{array}{l}\text { Baseline } \\
\text { Model }\end{array}$} & \multirow{2}{*}{$\begin{array}{l}\text { Nested } \\
\text { Model }\end{array}$} \\
\hline & $\begin{array}{c}\text { Std. } \\
\text { Estimate }\end{array}$ & $t$-Value & $\begin{array}{c}\text { Std. } \\
\text { Estimate }\end{array}$ & $t$-Value & & \\
\hline $\begin{array}{l}\text { Innovativeness } \rightarrow \\
\text { Citizenship } \\
\text { behavior toward } \\
\text { other visitors }\end{array}$ & 0.905 & $9.459 *$ & 0.569 & 4.964 * & $\begin{array}{c}\chi^{2}(362)= \\
587.192\end{array}$ & $\begin{array}{c}\chi^{2}(363)= \\
592.699\end{array}$ \\
\hline \multirow[t]{2}{*}{$\begin{array}{l}\text { Innovativeness } \rightarrow \\
\text { Citizenship } \\
\text { behavior toward } \\
\text { the exhibition }\end{array}$} & 0.895 & 9.091 * & 0.582 & 4.663 * & $\begin{array}{c}\chi^{2}(362)= \\
587.192\end{array}$ & $\begin{array}{c}\chi^{2}(363)= \\
590.795\end{array}$ \\
\hline & \multicolumn{6}{|c|}{$\begin{array}{l}\text { Chi-square difference test: } \\
=5.507, p<0.05 \text { (Significan } \\
3.603, p>0.05 \text { (Insignificant }\end{array}$} \\
\hline
\end{tabular}

The results of testing the hypotheses are shown in Figure 2.

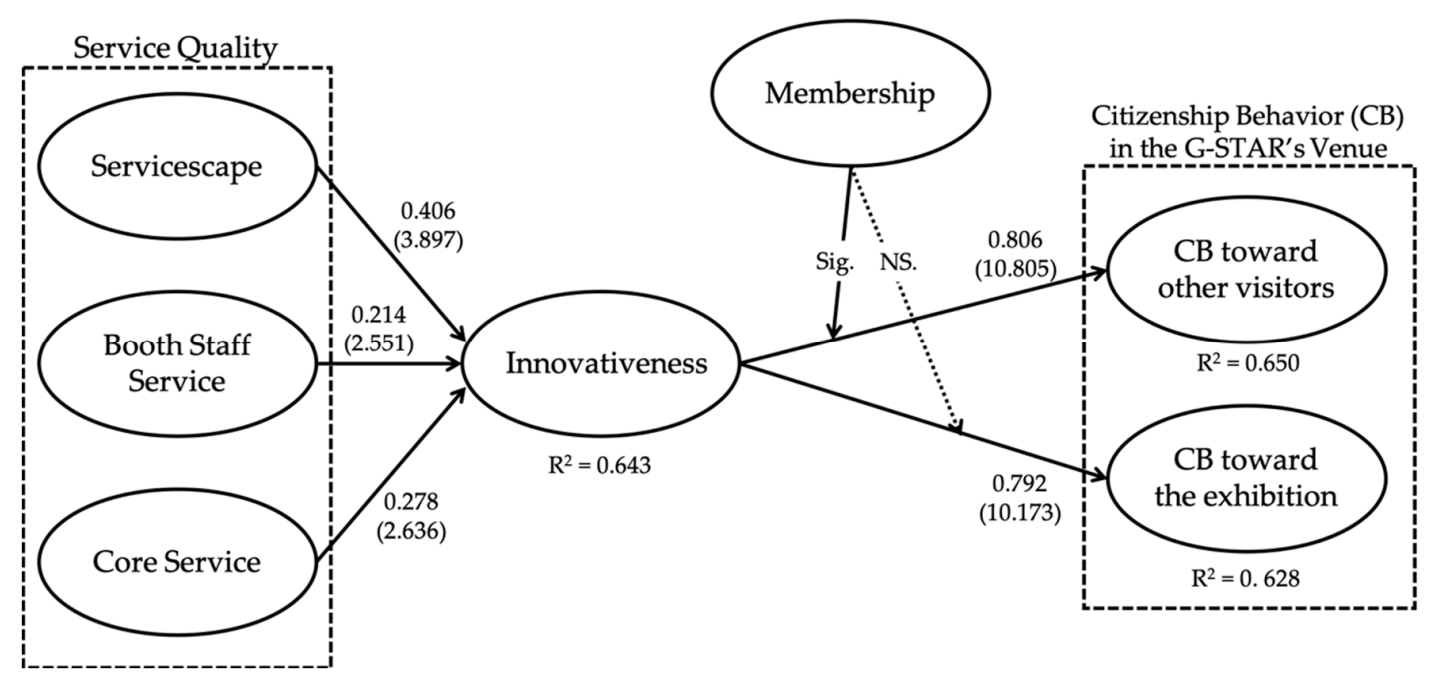

Figure 2. Final structural model. Note: $p<0.05$; Sig.= significant path; NS. = insignificant path.

\section{Discussion and Conclusions}

A large-scale exhibition like G-STAR plays an important role in presenting tangible products and visualizing intangible services within an industry. Creating innovativeness through various experiences is considered an essential factor that enhances the uniqueness and competitiveness of sustainable events such as an international game exhibition, contributing tremendously to a country's economic and social prosperity. In this regard, this study attempted to examine the extent to which service quality as a predictor affects innovativeness, to investigate the relationship between perceived innovativeness and visitors' citizenship behaviors in the context of game exhibitions, and to assess the moderating effect of membership on the relationship between innovativeness and visitors' citizenship behaviors. In summary, the results of SEM confirmed that all the hypotheses proposed within the research model were supported, except for H6b. More specifically, it appears that exhibition service quality elements, that is, the servicescape, booth staff service, and core service, are found to be significant predictors of innovativeness $(\mathrm{H} 1-\mathrm{H} 3)$. In particular, the servicescape made the most significant contribution to innovativeness, exhibiting the highest component loading, and the booth staff service and core service showed a moderate level of relevance to the perceived innovativeness of a game exhibition. This supports the results of Grace and O'Cass's [60] study, in which these 
three indicators show high correlations with service brand evidence, (i.e., "the set of service brand associations experienced by the consumer during the pre-purchase and consumption stage") [54] (p. 128). In terms of innovativeness, the construct was found to make significantly high contributions to both visitors' citizenship behaviors toward other visitors and visitors' citizenship behaviors toward a game exhibition (H4 and H5). In addition, the results suggest that the level of membership as perceived by visitors positively moderates the relationship between innovativeness and visitors' citizenship behaviors toward other visitors (H6a). Contrary to our expectations, however, the level of membership did not play a moderating role in the relationship between innovativeness and visitors' citizenship behaviors toward the exhibition (H6b). A plausible interpretation of such results is that the game exhibition's visitors formed a cohort of similar aged men with the same interests. According to the visitor demographics for the game exhibitions presented in this study, most of the visitors were under 30 years old and were male students who were highly interested in game products and services and the game industry. Therefore, it is assumed that one's perception of membership in the context of game exhibitions is more likely to be related to one's affiliation with a group of people who visit the same themed exhibition, rather than to the exhibition itself.

Proposing a conceptual model which encompasses the relationships between service quality, innovation, and visitors' citizenship behaviors, this study provides several theoretical implications to support sustainable exhibitions in the game industry. Firstly, the findings of this study contribute to the existing literature by providing a deeper understanding of the processes through which reciprocal relationships between exhibitors and visitors are formed within the service-dominant logic framework $[24,25,83]$. The service-dominant logic framework explains the value creation mechanism, which is focused on services in which both service providers and customers are active players in generating its shared value in a service environment, and the customers contribute to service value creation based on their experiences of interacting with the service provider $[25,84-88]$. The findings of this study show that the servicescape, booth staff's service, and core service of a game exhibition, collectively representing the service quality, can increase the value of visitors' exhibition experiences, as indicated in Berry [54]. That is, perceived innovativeness as an added value component can be enhanced by improving service quality in terms of the tangible elements (e.g., the physical facilities and equipment in the exhibition venue, such exhibitor booths, large screens, and newly launched game devices, as well as the physical attributes of exhibitors and the exhibition staff), the intangible elements of booth staff services (e.g., interpersonal interaction between the staff and visitors), and the core service of a game exhibition (e.g., processes, activities, and systems). This is consistent with the findings of previous studies $[19,41,54]$. The results of this study confirmed that exhibition visitors are not only potential customers but also value co-creators who can enrich service experiences in an exhibition setting, and they also proved that innovativeness can be co-created through various dimensions of exhibition service quality, advancing the improvement in service provision to achieve a sustainable competitive advantage in a game exhibition [89].

Secondly, this study conceptually contributes to the literature from different perspectives by suggesting and empirically testing a theoretical model of the value co-creation process in an exhibition setting, addressing the role of visitors as co-creators [20,21]. This study verified the positive relationships between service quality, innovativeness, and visitors' citizenship behaviors. Particularly, innovativeness had positive effects on visitors' citizenship behaviors toward other visitors and the exhibition. The results imply that visitors who perceive innovativeness through their exhibition experiences are likely to support the game exhibition and enhance other visitors' exhibition experiences at the venue. Perceived innovativeness can make game firms at exhibitions more distinct and competitive because visitors perceive new products and services, adopting new technologies and novel ideas. In addition, innovativeness motivates visitors' citizenship behaviors toward others and the event. For example, visitors may be willing to help friends and other visitors in finding products and services and explain how these offerings can be used correctly. In addition, they may be willing to provide their opinions on how the game exhibition can be improved and they may also recommend the exhibition to others. 
Visitors witnessing other visitors' citizenship behaviors are likely to show similar behaviors [23], and these actions can foster an awareness of the new products, services, and technologies that are being introduced by the exhibitors. To the best of our knowledge, the findings of this study are novel in that the service quality-innovativeness-citizenship behavior relationship has been elaborated through the service-dominant logic framework, focusing on the mutually reciprocal relationship between a service provider and its customers as co-creators of service value. Additionally, the results provide empirical evidence of the antecedents and consequences of innovativeness in the context of game exhibitions.

Thirdly, one of the most significant findings of this research is the moderating role of membership in the relationship between innovativeness and visitors' citizenship behaviors toward other visitors. The data analysis revealed that there was a significant difference in the effect of innovativeness on visitors' citizenship behaviors toward other visitors between the high and low membership groups. Meanwhile, regardless of the level of membership, game exhibition visitors who perceive high innovativeness in their game exhibition experiences were willing to engage in activities supporting the exhibition, and innovativeness was found to be more effective in leading visitors' citizenship behaviors toward other visitors in the high membership group. Those visitors with a stronger sense of membership were more likely to share information with and help others in the exhibition venue [70].

The results have several important managerial implications. Firstly, the results shed some light on how innovativeness can be fostered among exhibition visitors. A key implication is that exhibition visitors are more likely to perceive innovativeness through the physical setting of the exhibition, the exhibition's core service, and interactions with booth employees. Therefore, event managers should visualize new and distinct features of the products and services introduced at exhibition booths. Physical equipment, such as large screens, new game devices, and large venues, can facilitate the formation of innovativeness. Furthermore, exhibition booth employees may provide detailed information to visitors by giving specific instructions and hands-on demonstrations. Exhibitors and event managers should provide a variety of activities that can facilitate interactions between visitors and the booth staff. Such quality of intangible services provided by booth staff members may facilitate visitors' perceptions of innovativeness. For example, visitors need to wait in long lines at booths to try new games. In this situation, employees can provide mobile game trials and offer hands-on demonstrations for visitors who are waiting in-line before they experience new games at the booth. In addition, the core service provided should fit the exhibition visitors' needs and desires (e.g., short waiting time at the entrance, reasonable entrance fee, a novelty of game products and merchandise to purchase, a variety of performances and event programs to participate in, and the perceived suitability of the exhibitor mix) in order to generate exhibition visitors' higher perceptions innovativeness.

Secondly, the results indicate that membership moderated the effects of innovativeness on visitors' citizenship behaviors toward others. This suggests that those visitors with a sense of membership are more likely to help other visitors. The socialization between internal and external groups of visitors at the venue can facilitate their sharing of information with one another and build a sense of membership. Some possible suggestions include developing online or mobile platforms (e.g., social media) to regularly communicate with experienced game exhibition visitors. Social media interactions can increase the level of emotional engagement, motivate emotional responses to an event, and lead to a positive word-of-mouth intention [90]. By doing so, game exhibition managers can promote the firm-customer relationship, as well as the customer-customer relationship, and encourage visitors to attend the exhibition yearly. Additionally, e-mail or text marketing campaigns with video clips of the products/events to be showcased have the potential to maintain game exhibition attendance.

\section{Limitations and Suggestions for Future Research}

The results have important theoretical and practical implications for the processes through which reciprocal relationships between exhibitors and visitors are built in the context of international exhibitions. However, the study has several limitations. Firstly, a majority of respondents were in their early 20s, and individuals in such an age group are more likely to be active internet users 
and skilled smartphone users. As a result, they may be more likely to perceive innovativeness as stimulated by online communication and the latest information on new game products and services. This study provides an in-depth analysis of the distinct value fit in the context of an international exhibition in the game industry, namely G-STAR, and therefore future research should consider the distinct characteristics of the particular theme of a given exhibition and consider the appropriate target population for that exhibition. Secondly, the study considers visitors' citizenship behaviors toward others and the event only at the venue. Since the study focuses on the short-term effects of innovativeness and visitors' citizenship behaviors at the venue, future research should investigate the long-term effects of innovativeness by examining visitors' citizenship behaviors in offline and online contexts.

Author Contributions: Conceptualization, S.C., Y.-j.A., and I.K.; methodology, I.K.; writing—original draft preparation, Y.-j.A. and I.K.; writing-revision and editing, S.C.; supervision, I.K. All authors have read and agreed to the published version of the manuscript.

Funding: This research received no external funding

Conflicts of Interest: The authors declare no conflict of interest.

\section{References}

1. Wijman, T. The Global Games Market Will Generate \$152.1 Billion in 2019 as the U.S. Overtakes China as the Biggest Market. Available online: https:/newzoo.com/insights/articles/the-global-games-marketwill-generate-152-1-billion-in-2019-as-the-u-s-overtakes-china-as-the-biggest-market/ (accessed on 22 May 2020).

2. Statista. Size of the Gaming Market in South Korea from 2006 to 2021. Available online: https://www.statista. com/statistics/825058/south-korea-gaming-industry-size/ (accessed on 22 May 2020).

3. Newzoo. South Korea Games Market 2018. Available online: https://newzoo.com/insights/infographics/ south-korea-games-market-2018/ (accessed on 22 May 2020).

4. Lubek, S. 6 Leading Game Industry Trends to Watch in 2020. Available online: https://www.gamasutra.com/ blogs/SvenLubek/20191223/356058/6_Leading_Game_Industry_Trends_to_Watch_in_2020.php (accessed on 22 May 2020).

5. Abadzhiev, S. Player Support: A Game Changer in the Games Industry. Available online: https: //www.telusinternational.com/articles/player-support-a-game-changer-in-the-games-industry (accessed on 21 May 2016).

6. Luenendonk, M. The Gaming Industry-An Introduction. Available online: https://www.cleverism.com/ gaming-industry-introduction/ (accessed on 22 May 2020).

7. Andersson, T.D.; Armbrecht, J.; Lundberg, E. Linking event quality to economic impact: A study of quality, satisfaction, use value and expenditure at a music festival. J. Vacat. Mark. 2017, 23, 114-132. [CrossRef]

8. Rittichainuwat, B.; Mair, J. Visitor attendance motivations at consumer travel exhibitions. Tour. Manag. 2012, 33, 1236-1244. [CrossRef]

9. Jin, N.; Lee, H.; Lee, S. Event quality, perceived value, destination image, and behavioral intention of sports events: The case of the IAAF World Championship, Daegu, 2011. Asia Pac. J. Tour. Res. 2013, 18, 849-864. [CrossRef]

10. Haps Korea. City to Host Game Exhibition for Four More Years. Available online: https://www.hapskorea. com/city-host-game-exhibition-four-more-years (accessed on 27 December 2014).

11. Hede, A.M.; Kellett, P. Marketing communications for special events: Analysing managerial practice, consumer perceptions and preferences. Eur. J. Mark. 2011, 45, 987-1004. [CrossRef]

12. Danneels, E.; Kleinschmidtb, E.J. Product innovativeness from the firm's perspective: Its dimensions and their relation with project selection and performance. J. Prod. Innov. Manag. 2001, 18, 357-373. [CrossRef]

13. Jasrai, L. Measuring mobile telecom service innovativeness among youth: An application of domain-specific innovativeness scale. Paradigm 2014, 18, 103-116.

14. Kunz, W.; Schmitt, B.; Meyer, A. How does perceived firm innovativeness affect the consumer? J. Bus. Res. 2011, 64, 816-822. [CrossRef] 
15. Hyun, S.S.; Han, H. A model of a patron's innovativeness formation toward a chain restaurant brand. Int. J. Contemp. Hosp. Manag. 2012, 24, 175-199. [CrossRef]

16. Kang, M.; Gretzel, U. Perceptions of museum podcast tours: Effects of consumer innovativeness, Internet familiarity and podcasting affinity on performance expectancies. Tour. Manag. Perspect. 2012, 4, 155-163. [CrossRef]

17. Couture, A.; Arcand, M.; Sénécal, S.; Ouellet, J.-F. The influence of tourism innovativeness on online consumer behavior. J. Travel Res. 2015, 54, 66-79. [CrossRef]

18. Yoshida, M.; James, J.D.; Cronin, J.J., Jr. Sport event innovativeness: Conceptualization, measurement, and its impact on consumer behavior. Sport Manag. Rev. 2013, 16, 68-84. [CrossRef]

19. Gottlieb, U.R.; Brown, M.R.; Drennan, J. The influence of service quality and trade show effectiveness on post-show purchase intention. Eur. J. Mark. 2011, 45, 1642-1659. [CrossRef]

20. Chathoth, P.; Altinay, L.; Harrington, R.J.; Okumus, F.; Chan, E.S.W. Co-production versus co-creation: A process based continuum in the hotel service context. Int. J. Hosp. Manag. 2013, 32, 11-20. [CrossRef]

21. Shaw, G.; Bailey, A.; Williams, A. Aspects of service-dominant logic and its implications for tourism management: Examples from the hotel industry. Tour. Manag. 2011, 32, 207-214. [CrossRef]

22. Chathoth, P.K.; Ungson, G.R.; Harrington, R.J.; Chan, E.S.W. Co-creation and higher order customer engagement in hospitality and tourism services: A critical review. Int. J. Contemp. Hosp. Manag. 2016, 28, 222-245. [CrossRef]

23. Yi, Y.; Gong, T.; Lee, H. The impact of other customers on customer citizenship behavior. Psychol. Mark. 2013, 30, 341-356. [CrossRef]

24. Lusch, R.F.; Vargo, S.L.; O’Brien, M. Competing through service: Insights from service-dominant logic. J. Retail. 2007, 83, 5-18. [CrossRef]

25. Vargo, S.L.; Lusch, R.F. Evolving to a new dominant logic for marketing. J. Mark. 2004, 68, 1-17. [CrossRef]

26. Amue, G.J.; Adiele, K.C. New product development and consumer innovative behaviour: An empirical validation study. Eur. J. Bus. Soc. Sci. 2012, 1, 97-109.

27. Roehrich, G. Consumer innovativeness: Concepts and measurements. J. Bus. Res. 2004, 57, 671-677. [CrossRef]

28. Hurley, R.F.; Hult, G.T.M. Innovation, market orientation, and organizational learning: An integration and empirical examination. J. Mark. 1998, 62, 42-54. [CrossRef]

29. Chiou, J.-S.; Hsieh, C.-H.; Shen, C.-C. Product innovativeness, trade show strategy and trade show performance: The case of Taiwanese global information technology firms. J. Glob. Mark. 2007, 20, 31-42. [CrossRef]

30. Lee, Y.; Kim, I. Investigating key innovation capabilities fostering visitors' mindfulness and its consequences in the food exposition environment. J. Travel Tour. Mark. 2018, 35, 803-818. [CrossRef]

31. Hwang, J.; Kim, H.; Kim, W. Investigating motivated consumer innovativeness in the context of drone food delivery services. J. Hosp. Tour. Manag. 2019, 38, 102-110. [CrossRef]

32. Hwang, J.; Lee, J.-S.; Kim, H. Perceived innovativeness of drone food delivery services and its impacts on attitude and behavioral intentions: The moderating role of gender and age. Int. J. Hosp. Manag. 2019, 81, 94-103. [CrossRef]

33. Goldsmith, R.E.; Hofacker, C.F. Measuring consumer innovativeness. J. Acad. Mark. Sci. 1991, 19, $209-221$. [CrossRef]

34. Kim, I.; Kim, J.J. Older adults' parasocial interaction formation process in the context of travel websites: The moderating role of parent-child geographic proximity. Tour. Manag. 2017, 63, 399-416. [CrossRef]

35. Zeithaml, V.A. Consumer perceptions of price, quality, and value: A means-end model and synthesis of evidence. J. Mark. 1988, 52, 2-22. [CrossRef]

36. Cronin, J.J., Jr.; Taylor, S.A. Measuring service quality: A reexamination and extension. J. Mark. 1992, 56, 55-68. [CrossRef]

37. Fullerton, G. The service quality-loyalty relationship in retail services: Does commitment matter? J. Retail. Consum. Serv. 2005, 12, 99-111. [CrossRef]

38. Rust, R.T.; Oliver, R.L. Service quality: Insights and managerial implications from the frontier. In Service Quality: New Directions in Theory and Practice; Rust, R.T., Oliver, R.L., Eds.; Sage: London, UK, 1994; pp. 1-19, ISBN 9780803949201. 
39. Parasuraman, A.; Zeithaml, V.A.; Berry, L.L. SERVQUAL: A multiple-item scale for measuring consumer perceptions of service quality. J. Retail. 1988, 64, 12-40.

40. Brady, M.K.; Cronin, J.J., Jr. Some new thoughts on conceptualizing perceived service quality: A hierarchical approach. J. Mark. 2001, 65, 34-49. [CrossRef]

41. Kyle, G.T.; Theodorakis, N.D.; Karageorgiou, A.; Lafazani, M. The effect of service quality on customer loyalty within the context of ski resorts. J. Park Recreat. Adm. 2010, 28, 1-15.

42. Zeithaml, V.A.; Berry, L.L.; Parasuraman, A. The behavioral consequences of service quality. J. Mark. 1996, 60, 31-46. [CrossRef]

43. Han, H.; Eom, T.; Chung, H.; Lee, S.; Ryu, H.; Kim, W. Passenger repurchase behaviours in the green cruise line context: Exploring the role of quality, image, and physical environment. Sustainability 2019, 11, 1985. [CrossRef]

44. Hwang, J.; Asif, M.; Lee, K.-W. Relationships among country image, tour motivations, tour quality, tour satisfaction, and attitudinal loyalty: The case of Chinese travelers to Korea. Sustainability 2020, $12,3182$. [CrossRef]

45. Han, H.; Hwang, J. Quality of physical surroundings and service encounters, airfare, trust and intention during the flight: Age-group difference (young, middle-aged, and mature). Int. J. Contemp. Hosp. Manag. 2015, 27, 585-607. [CrossRef]

46. Han, H.; Hwang, J. In-flight physical surroundings: Quality, satisfaction, and traveller loyalty in the emerging low-cost flight market. Curr. Issues Tour. 2017, 20, 1336-1354. [CrossRef]

47. Brodie, R.J.; Whittome, J.R.M.; Brush, G.J. Investigating the service brand: A customer value perspective. J. Bus. Res. 2009, 62, 345-355. [CrossRef]

48. Bitner, M.J. Servicescapes: The impact of physical surroundings on customers and employees. J. Mark. 1992, 56, 57-71. [CrossRef]

49. Lee, S.; Chua, B.-L.; Han, H. Role of service encounter and physical environment performances, novelty, satisfaction, and affective commitment in generating cruise passenger loyalty. Asia Pac. J. Tour. Res. 2016, 22, 131-146. [CrossRef]

50. Lee, Y.-K.; Lee, C.-K.; Lee, S.-K.; Babin, B.J. Festivalscapes and patrons' emotions, satisfaction, and loyalty. J. Bus. Res. 2008, 61, 56-64. [CrossRef]

51. Yoon, Y.-S.; Lee, J.-S.; Lee, C.-K. Measuring festival quality and value affecting visitors' satisfaction and loyalty using a structural approach. Int. J. Hosp. Manag. 2010, 29, 335-342. [CrossRef]

52. Theodorakis, N.D.; Kaplanidou, K.; Alexandris, K.; Papadimitriou, D. From sport event quality to quality of life: The role of satisfaction and purchase happiness. J. Conv. Event Tour. 2019, 20, 241-260. [CrossRef]

53. Kyrgidou, L.P.; Spyropoulou, S. Drivers and performance outcomes of innovativeness: An empirical study. Br. J. Manag. 2013, 24, 281-298. [CrossRef]

54. Berry, L.L. Cultivating service brand equity. J. Acad. Mark. Sci. 2000, 28, 128-137. [CrossRef]

55. Han, H.; Yu, J.; Lee, H. Lovemarks and effect of in-flight product performance on airline passengers' purchase intention. Soc. Behav. Personal. 2020, 48, 1-10. [CrossRef]

56. O'Cass, A.; Grace, D. Exploring consumer experiences with a service brand. J. Prod. Brand Manag. 2004, 13, 257-268. [CrossRef]

57. de Ruyter, K.; Wetzels, M.; Kleijnen, M. Customer adoption of e-service: An experimental study. Int. J. Serv. Ind. Manag. 2001, 12, 184-207. [CrossRef]

58. Han, H.; Yu, J.; Chua, B.-L.; Lee, S.; Kim, W. Impact of core-product and service-encounter quality, attitude, image, trust and love on repurchase: Full-service vs low-cost carriers in South Korea. Int. J. Contemp. Hosp. Manag. 2019, 31, 1588-1608. [CrossRef]

59. Alexandris, K.; Kouthouris, C.; Meligdis, A. Increasing customers' loyalty in a skiing resort: The contribution of place attachment and service quality. Int. J. Contemp. Hosp. Manag. 2006, 18, 414-425. [CrossRef]

60. Grace, D.; O'Cass, A. Service branding: Consumer verdicts on service brand. J. Retail. Consum. Serv. 2005, 12, 125-139. [CrossRef]

61. Arli, D.; Grace, A.; Palmer, J.; Pham, C. Investigating the direct and indirect effects of corporate hypocrisy and perceived corporate reputation on consumers' attitudes toward the company. J. Retail. Consum. Serv. 2017, 37, 139-145. [CrossRef]

62. Jones, M.A.; Mothersbaugh, D.L.; Beatty, S.E. Switching barriers and repurchase intentions in services. J. Retail. 2000, 76, 259-274. [CrossRef] 
63. Grönroos, C. Strategic Management and Marketing in the Service Sector; Marketing Science Institute: Cambridge, MA, USA, 1984; ISBN 9789144439112.

64. Groth, M. Customers as good soldiers: Examining citizenship behaviors in Internet service deliveries. J. Manag. 2005, 31, 7-27. [CrossRef]

65. Bettencourt, L. Customer voluntary performance: Customers as partners in service delivery. J. Retail. 1997, 73, 383-406. [CrossRef]

66. Kim, J.J.; Kim, I. Moral imagination, parasocial brand love, and customer citizenship behavior: Travelers' relationship with sponsoring airline brands in the United States. Sustainability 2018, 10, 4391. [CrossRef]

67. van Doorn, J.; Lemon, K.N.; Mittal, V.; Nass, S.; Pick, D.; Pirner, P.; Verhoef, P.C. Customer engagement behavior: Theoretical foundations and research directions. J. Serv. Res. 2010, 13, 253-266. [CrossRef]

68. Tajfel, H.; Turner, J.C. The social identity theory of intergroup behavior. In Psychology of Intergroup Relations; Worchel, S., Austin, W.G., Eds.; Nelson-Hall: Chicago, IL, USA, 1986; pp. 7-24. ISBN 9780830410750.

69. Hsu, C.-L.; Lin, J.C.-C. Acceptance of blog usage: The roles of technology acceptance, social influence and knowledge sharing motivation. Inf. Manag. 2008, 45, 65-74. [CrossRef]

70. Chai, S.; Kim, M. A socio-technical approach to knowledge contribution behavior: An empirical investigation of social networking sites users. Int. J. Inf. Manag. 2012, 32, 118-126. [CrossRef]

71. Choi, S.; Kim, I.; Cha, K.; Suh, Y.-K.; Kim, K.-H. Travelers' parasocial interactions in online travel communities. J. Travel Tour. Mark. 2019, 36, 888-904. [CrossRef]

72. G-STAR 2014. G-STAR 2014 Global Game Exhibition. Available online: https://english.busan.go.kr/bsnews01/ 797364 (accessed on 20 April 2020).

73. Business Wire. The Largest ever "G-STAR 2014" Ended in Great Success. Available online: https://www.businesswire.com/news/home/20141128005077/en/\%C2\%A0\%C2\%A0\%C2\%A0The-LargestG-STAR-2014-Ended-Great-Success (accessed on 22 May 2020).

74. Hair, J.F., Jr.; Black, W.C.; Babin, B.J.; Anderson, R.E. Multivariate Data Analysis: A Global Perspective, 7th ed.; Prentice Hall: Upper Saddle River, NJ, USA, 2010; ISBN 9780135153093.

75. Koh, J.; Kim, Y.-G. Sense of virtual community: A conceptual framework and empirical validation. Int. J. Electron. Commer. 2003, 8, 75-93. [CrossRef]

76. Lin, H.-F. Determinants of successful virtual communities: Contributions from system characteristics and social factors. Inf. Manag. 2008, 45, 522-527. [CrossRef]

77. Anderson, J.C.; Gerbing, D.W. Structural equation modeling in practice: A review and recommended two-step approach. Psychol. Bull. 1988, 103, 411-423. [CrossRef]

78. Ahn, J.B. [Survey] How Was G-Star? Available online: https://www.thisisgame.com/webzine/nboard/4/ ?xkdlq=0\&amp;page $=486 \&$ amp;n=57170 (accessed on 22 May 2020).

79. Morris, T. 4 Gaming Trends to Get Excited about in 2020. Available online: https://blog.globalwebindex.com/ chart-of-the-week/gaming-trends-2020/ (accessed on 22 May 2020).

80. Byrne, B.M. Structural Equation Modeling with AMOS: Basic Concepts, Applications, and Programming; Lawrence Erlbaum Associates: Mahwah, NJ, USA, 2001; ISBN 9780805833225.

81. Bagozzi, R.P.; Yi, Y. On the evaluation of structural equation models. J. Acad. Mark. Sci. 1988, 16, 74-94. [CrossRef]

82. Fornell, C.; Larcker, D.F. Evaluating structural equation models with unobservable variables and measurement error. J. Mark. Res. 1981, 18, 39-50. [CrossRef]

83. Vargo, S.L.; Lusch, R.F. Institutions and axioms: An extension and update of service-dominant logic. J. Acad. Mark. Sci. 2016, 44, 5-23. [CrossRef]

84. Vargo, S.L.; Lusch, R.F. Why “service"? J. Acad. Mark. Sci. 2008, 36, 25-38. [CrossRef]

85. Vargo, S.L.; Lusch, R.F. Service-dominant logic: Continuing the evolution. J. Acad. Mark. Sci. 2008, 36, 1-10. [CrossRef]

86. Lee, Y.; Kim, L. A value co-creation model in brand tribes: The effect of luxury cruise consumers' power perception. Serv. Bus. 2019, 13, 129-152. [CrossRef]

87. Hwang, J.; Park, S. An exploratory study of how casino dealer communication styles lead to player satisfaction. J. Travel Tour. Mark. 2018, 35, 1246-1260. [CrossRef]

88. Hwang, J.; Lee, J. Antecedents and consequences of brand prestige of package tour in the senior tourism industry. Asia Pac. J. Tour. Res. 2019, 24, 679-695. [CrossRef] 
89. Evans, N.G. Sustainable competitive advantage in tourism organizations: A strategic model applying service dominant logic and tourism's defining characteristics. Tour. Manag. Perspect. 2016, 18, 14-25. [CrossRef]

90. Hudson, S.; Roth, M.S.; Madden, T.J.; Hudson, R. The effects of social media on emotions, brand relationship quality, and word of mouth: An empirical study of music festival attendees. Tour. Manag. 2015, 47, 68-76. [CrossRef] 